\title{
CHRONOLOGY OF AEOLIAN EVENTS RECORDED IN THE KARCZMISKA DUNE (LUBLIN UPLAND) IN THE LIGHT OF LITHOFACIAL ANALYSIS, ${ }^{14} \mathrm{C}$ AND TL DATING
}

\author{
STANISLAW FEDOROWICZ ${ }^{1}$ and PAWEL ZIELIŃSKI ${ }^{2}$ \\ ${ }^{1}$ Department of Geomorphology and Quaternary Geology, University of Gdańsk, \\ Dmowskiego 16a, 80-950 Gdańsk, Poland \\ ${ }^{2}$ Department of Physical Geography and Paleogeography, Maria Curie-Skłodowska University, \\ Kraśnicka 2cd, 20-718 Lublin, Poland
}

Received 20 January 2009

Accepted 30 June 2009

\begin{abstract}
The article studies an average-size parabolic dune located in the northern part of the Chodel Basin, Lublin Upland, Poland within the extensive dune field which covers the contact area of the loess patch slope and the high sandy terrace. Its complex structure and the presence of terrace sand and loess in the floor inspired the authors to conduct detailed lithological studies, as well as TL and ${ }^{14} \mathrm{C}$ dating. As a result, it was possible to determine the mechanism and age of aeolian accumulation cycles in the dune, which contains very good representative evidence of aeolian events in the Lublin Upland.
\end{abstract}

Keywords: TL, C14, aeolian deposition, dunes, Late Vistulian

\section{INTRODUCTION}

Research on inland dunes places most emphasis on specifying the number, age and duration of aeolian phases in deposition processes. It depends on: a) form structure, in particular the presence of fossil soil or deflation surfaces that separate aeolian series of various ages; b) geological conditions of the dune location, with the most advantageous situation being when aeolian sand interfinger with biogenic deposits; and c) access to the form structure, which is mainly connected with large mining outcrops and an adequately low level of groundwater. Studies are conducted on the basis of: a) morphologicallithographical description of dune forms (Wojtanowicz, 1969; Mycielska Dowgiałło, 1982); b) radiocarbon dating and palynological analysis of fossil soils in dunes and/or organogenic horizons in dune substratum or in deflation basins (Kozarski, 1962; Tobolski, 1988; Rotnicki, 1970; Nowaczyk, 1976, 1986; Krajewski, 1977; Manikowska, 1970, 1985, 1991, 1995; Krajewski and Balwierz, 1985; Szczypek, 1986; Kozarski and Nowaczyk, 1991, 1992); and c) TL dating (Buraczyński, 1994; Jaśkowski, 1996;

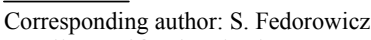
e-mail: geosf@univ.gda.pl
Wojtanowicz, 1999; Zieliński et al., 2008) and OSL dating (Muray and Clemensen, 2001) of aeolian deposits and their mineral substratum. The largest numbers of studies concern the Central European Lowland dunes. There are only few studies related to the Lublin Upland (Manikowska, 1970; Zieliński, 1999).

The results of Zieliński's lithological studies (2004, 2006) inspired the authors to scrutinize the possibility of applying TL dating to specify the chronology of events and the duration of aeolian deposition. For this purpose the authors selected a middle-size parabolic dune, which is the most common aeolian sand form in the Lublin Upland (Fig. 1). This form was chosen due to: 1) its location on loess deposits of aeolian origin - which is generally regarded as the best TL dating material (Bluszcz, 2000; Fedorowicz, 2006); it will facilitate specifying the lower date of dune accumulation as precisely as possible, and comparing the deposition rate of loess and dune sands; 2) complex structure and good access to the form structure, which allow for the specification of aeolian event chronology with high probability; and 3) existence of fossil soil layers, which permits juxtaposing the obtained TL dates with radiocarbon dates.

The field studies consisted of: a) recording the texture and structure of deposits contained in the form and its 


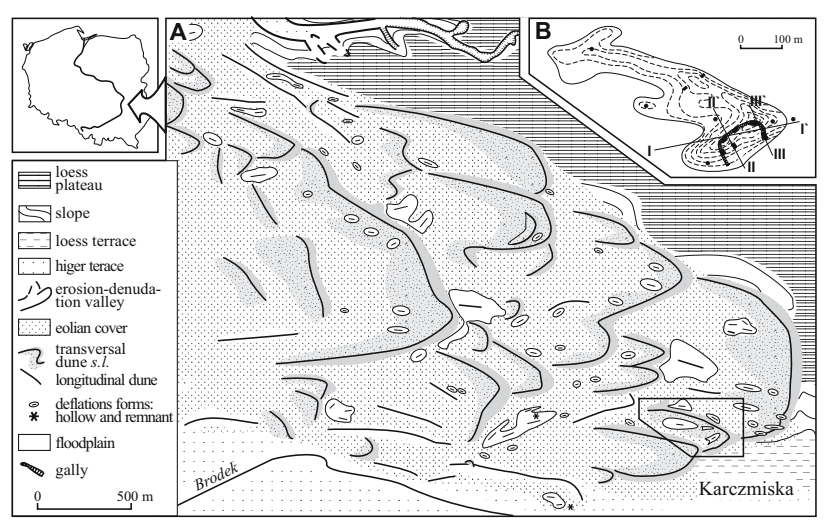

Fig. 1. Location of the form in the geomorphological sketch of Karczmiska dune field $(A)$; configuration of dune surface and localization of profile lines $(B)$.

direct substratum; b) measuring structural directional elements; and c) collecting samples for radiocarbon and TL dating. The lithofacial features of deposits determined in the field studies were used to identify the primary deposition environment according to Hunter's (1977) and Borówka's (2001) classifications. As a result, the sequence of aeolian events was reconstructed while dating contributed to their allocation to relevant periods of time.

\section{TL DATING METHOD}

The TL dating method used in the TL laboratory of the Gdańsk University was described by Fedorowicz (2006). At first sample moisture is measured. The dose rate (Dr) is determined for a dried sample with use of the "MAZAR-95" gamma spectrometer. The concentrations of ${ }^{226} \mathrm{Ra},{ }^{232} \mathrm{Th},{ }^{40} \mathrm{~K}$ in dry mass are measured in the Marinelli type containers $0.5 \mathrm{dm}^{3}$ in volume. One sample is measured 20 times, each measurement lasts $2000 \mathrm{~s}$. The concentrations of radionuclides are converted into dose rates for alpha, beta and gamma radiation. The dose rate is calculated with the corrections for deposit moisture, dose of cosmic radiation, grain size, and time of etching with HF (Aitken and Xie, 1983; Adamiec and Aitken, 1998). Uncertainty of dose rate determination is about 3\% (Poręba and Fedorowicz, 2005). Three or four predominant grain fractions are separated from each sample of aeolian sands and processed in order to remove carbonates and organic material. At first grains are treated with $10 \% \mathrm{HCl}$ for about twenty-four hours, and then with $2 \% \mathrm{NaOH}$ for the same time. After washing, grains are etched with $40 \%$ HF by 45 minutes in order to remove the outer layer of quartz and dissolve grains of other minerals (Bluszcz, 2000). Washed material is divided into several portions that are used to determine the equivalent dose (ED) by the TL multiple-aliquot regeneration technique. The TL glow curves are recorded with use of the RA'94TL reader-analyser (produced by Mikrolab Kraków) with the EMI 9789 QA photomultiplier. Aliquots are glowed out in argon atmosphere at a heating rate of $8^{\circ} \mathrm{C} / \mathrm{s}$ up to $400^{\circ} \mathrm{C}$. The optical filter BG-28 (380$500 \mathrm{~mm}$ ) is used. Bleaching experiments show that residual TL intensity of $375^{\circ} \mathrm{C}$ peak, of the quartz, is obtained after $8 \mathrm{~h}$ of sunlight exposition. Plateau test is carried out for each sample (it occurs between $320^{\circ} \mathrm{C}$ and $380^{\circ} \mathrm{C}$ ). Grain sensitivity is tested by additional measurements according to technique used in additive method. The component from $\alpha$ radiation is not included in the $\mathrm{Dr}$ calculation on account of large grain size $(80-315 \mu \mathrm{m})$, and the same Dr value is taken for all examined grain fractions (Table 2). In order to determine the equivalent dose, the samples are irradiated with 5 additional gamma doses from 10 to 100 Gy $(10,20,30,50,100$ Gy). Dose response is calculated with the FIT-SIM programme of Grün (1994) which is based on the simplex fitting procedures and analytical error calculation by Brumby (1992).

\section{FORM DESCRIPTION}

The form is located north west from Karczmiska (Fig. 1), within the extensive dune field in the northern part of the Chodel Basin (Lublin Upland), which covers the contact area of the high sandy Vistulian terrace and the slope of loess patch with the SW exposure.

\section{Morphological and geological situation}

The dune is a middle-size form with the W-E orientation (Fig. 1B). It is 6 metres high in the front part and its ridge is ca. $600 \mathrm{~m}$ long. In the closest vicinity there are sandy deposits which become silty eastwards. These deposits are also the direct substratum of the dune.

\section{Form structure}

The form structure was documented in the excavation site which cuts its southern arm, proximal part of the dune front and its substratum. The loess found in the dune substratum is strongly ferruginous and gleyed, and a distinct gley horizon occurs in the loess top. The dune consists of four series separated from each other with fossil soil layers, erosion surface or discordance zone (Fig. 2).

The first dune series (Figs. 2, 3D, G), in its western part, is composed of fine and medium-grained sand with climbing ripple lamination or translatent stratification, and coarse sand and very fine gravel with massive structure or, occasionally, inclined cross-lamination. The middle and eastern parts of the series consist of sand with high-angle inclined stratification. Sandy packages of large longitudinal extent and small transverse extent are accompanied by similarly distributed packages of finer material, but of much greater transverse extent, with massive structure or faint lamination, predominant mainly in the bottom part of the series. The structural directional elements show ESE preferences.

The second series covers the first one in its western part (Figs. 2, 3B, C). It consists of fine and mediumgrained sand with high-angle inclined stratification. Sandy packages of small transverse extent alternate with packages of finer material of large transverse extent, which are replaced by fine sand and silt with faint lamination in the bottom part of the series. The layers dip in the eastern direction.

The third series occurs on the first one in its eastern and middle part (Figs. 2, 3B, E, F). It is separated from the first series by the erosion surface and from the second 


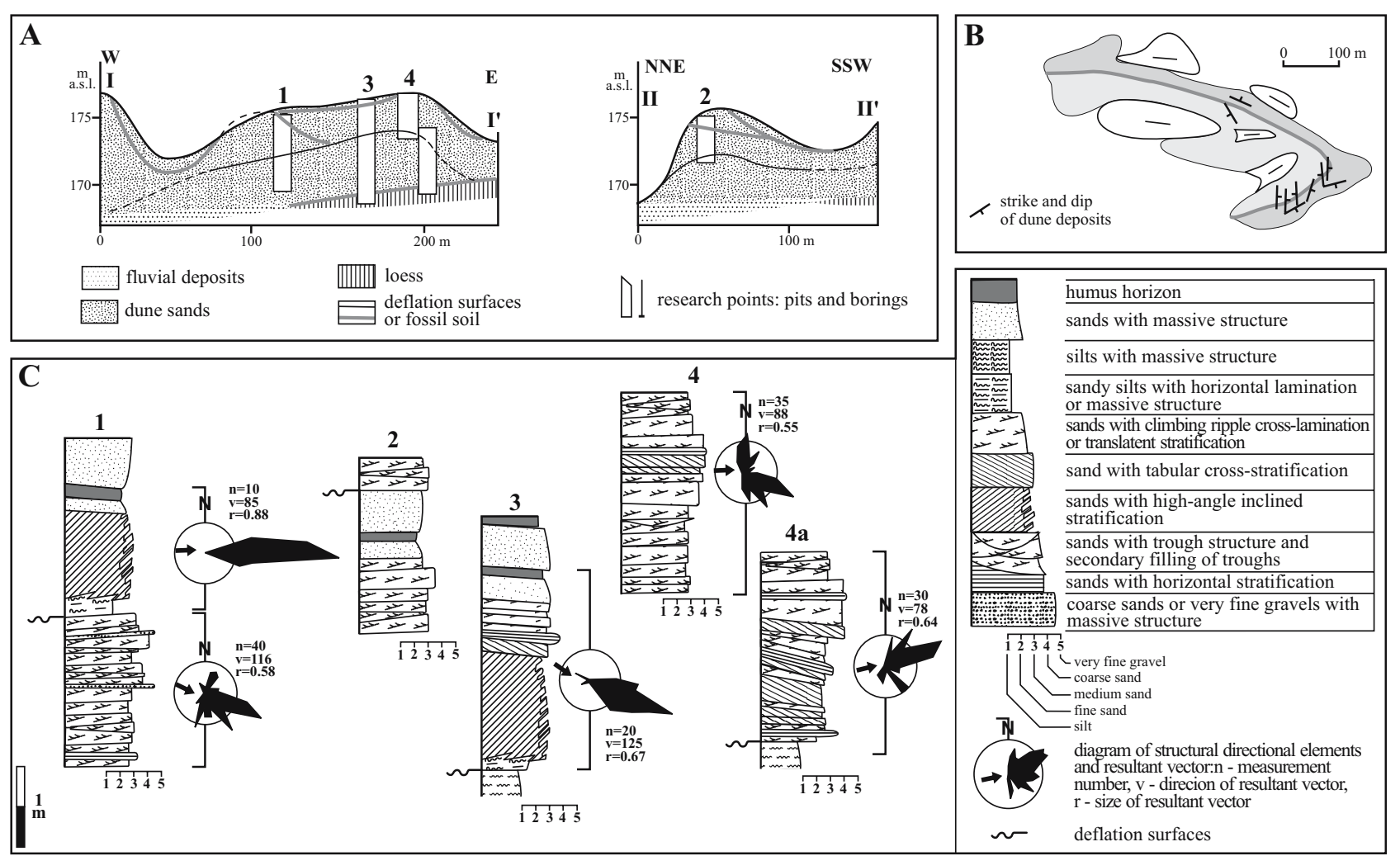

Fig. 2. Details of form structure: A-simplified geological profiles, localization in Fig. 2B; B-run and dip of deposit layers; C-detailed sedimentation profiles.

series by fossil soil. The series is formed by varigrained sand that generally has massive structure within the proximal slope; climbing ripple lamination or translatent stratificationis noticeable only in the bottom part. The dune ridge zone is composed of (Figs. 2, 3F) sand with translatent stratification or tabular cross-stratification of small and medium scale. Single troughs of concordant fill occur accessorily (Fig. 3E). The structural directional elements are arranged from $\mathrm{N}$ to $\mathrm{SE}$.

The fourth series (Fig. 2), which lies at the level of soil formed in the top of the third series, covers partially the proximal and distal slope of the dune. It is composed of medium-grained sand with climbing ripple lamination and translatent stratification.

\section{Interpretation}

The structure of the first series in its western part, i.e. sand with climbing ripple lamination and translatent stratification, indicates that its depositions resulted from the migration of ripples; therefore, the deposition surface was exposed to wind (Bagnold, 1954; Sharp, 1963; Hunter, 1977). Similar conclusions may be drawn from the documented coarse sand and very fine gravel with massive structure and cross-stratification, which evidence the existence of gravel ripples. In addition to the increase in the wind velocity, they may indicate the change of alimentation area (Sharp, 1963; Fryberger et al., 1992). The surface exposed to wind suggests that it was formed on the windward slope of the dune. The structure of the series in its eastern part, i.e. sand with high-angle inclined stratification, indicates that this part was formed on the leeward slope of the dune. Sandy packages are typical of sandflow down the slope with inclination close to the angle of repose (Bagnold, 1954; Mc Kee, 1966; Mc Kee et al., 1971; Hunter, 1977, Borówka, 1980; Lea, 1990). Fine-grained interbeddings may be connected with the deposition of suspended material due to the reduced carrying capacity of wind stream on the leeward slope of the dune (Mc Kee, 1966, Sharp, 1966; Hunter, 1977, Clemmensen and Abrahamsen, 1983; Lea, 1990). The structural documentation of the windward and leeward slopes in the first series points to a stationary dune (Rotnicki, 1970; Nowaczyk, 1976, Zieliński, 2004; Zieliński and Issmer, 2008) while the definite predominance, in the series structure, of lithofacies typical of a distal slope means that the dune made a small movement on a distance not smaller than its base (Nowaczyk, 1976; Zieliński, 2004; Zieliński and Issmer, 2008).

Lithofacial features of the second series, i.e. sand of high-angle inclined stratification and fine sand and silt interbeddings, typical of leeward slopes, help to link its origin with the migrating form. Sand and silt of faint lamination, which were documented in the bottom part of the series and suggest deposition caused by ripple migration, result from the separation of airflow and formation of back eddies (Hunter, 1977; Clemmensen and Abrahamsen, 1983). The deposition effect of this series was a migrating dune which moved eastwards and stopped on the proximal slope of the dune represented by the first series.

The third series was accumulated in changeable conditions. A high share of sand with translatent stratification and climbing ripple lamination suggests the windward deposition environment; therefore, the surface was 


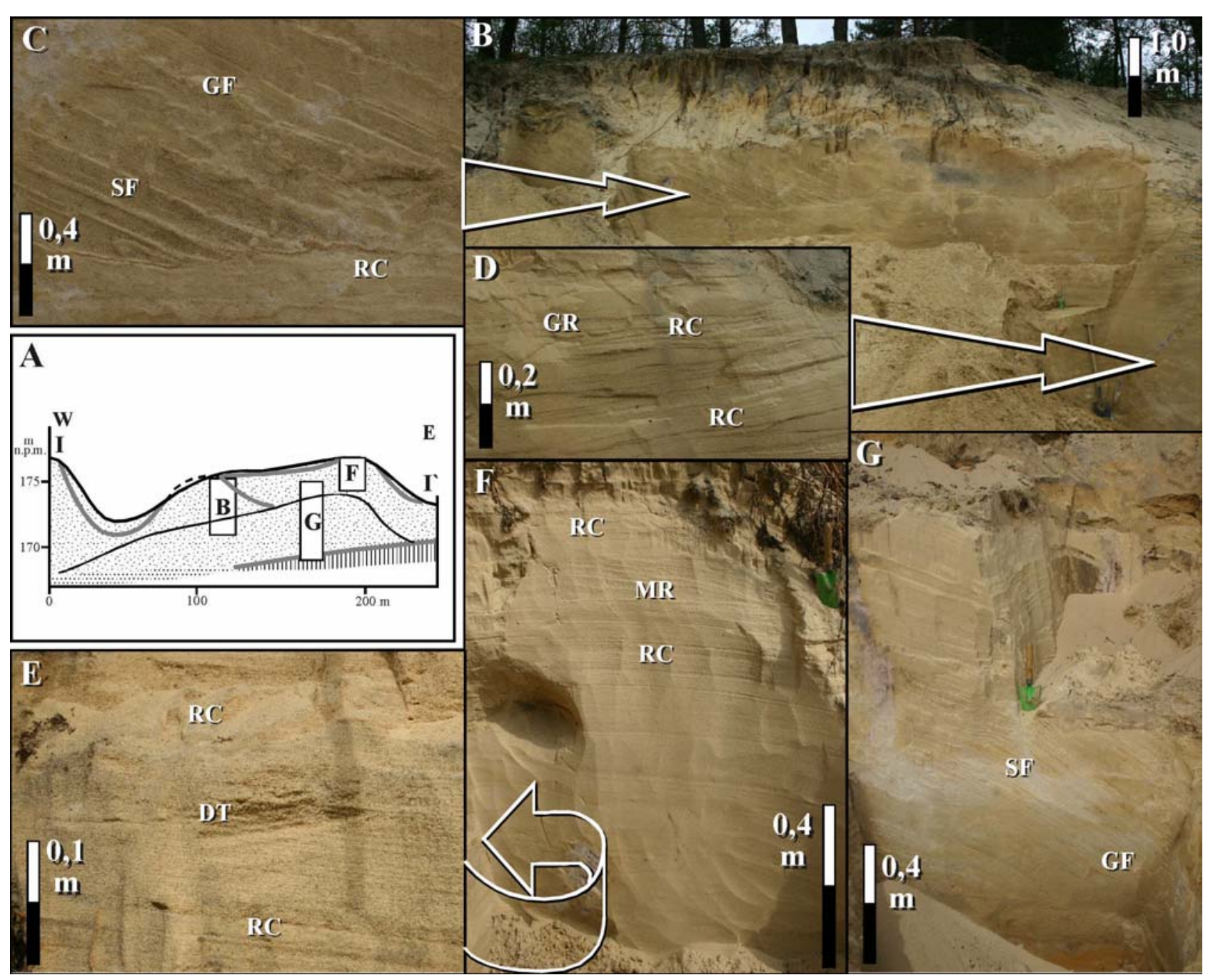

Fig. 3. Form structure: $A$ - photograph localization in the section of the form; $B$ - contact of the first, second and third dune series; $C$ - details of the bottom part of the second series; $D$ - structure of the first series; $E, F$ - details of the third series structure in the dune ridge area; $G$ - loess top, structure of the first series in its eastern part. Letter marks on photographs after Zieliński and Issmer (2008): RC - climbing ripples, MR - megaripples, $R G$ - granule ripples, DT - deflation troughs, SF - sandflow, GF - grain fall.

exposed to wind and the formation of massive-structure sand may be explained twofold. Its formation (the socalled structureless layer) is most frequently contributed to soil processes (Wojtanowicz, 1970) or structure obliteration in periglacial conditions (Stankowski, 1963; Urbaniak, 1969) and if this is the case, it is difficult to specify the original deposition environment. However, it is difficult to arrive at a definite conclusion due to the small thickness of the third series and its coverage in this place by the well-developed fossil soil, which in turn supports the first interpretation. The tabular cross-stratified sand documented in the ridge area of the third series suggests the migration of mesoforms, i.e. megaripples (Pye and Tsoar, 1990; Borówka, 1990 2001; Goździk, 1998).

Their presence and single deflation troughs evidence the increased wind velocity, which contributed to the higher deposition rate at the initial phase, developing into the reduction (deflation) of the deposited material at a later stage (Mc Kee, 1966; Zieliński and Issmer, 2008). The documented wind direction points to high variation from South to Northern West; a minor stabilization may be observed for strong wind causing deflation, i.e. from the
NW-WNW sector. As a result of the deposition in the series, two smaller forms combined into a single large parabolic dune, the size of which was slightly larger than the present size. The fourth series results from deflation and deposition processes within the form.

\section{DETERMINATION OF DEPOSITION AGE}

Three radiocarbon dates of fossil soils and $38 \mathrm{TL}$ dates (Fig. 4) in 9 samples from dune sand (Table 2) and in 5 loess samples (Table 1) were obtained.

Radiocarbon dates clearly separate three phases of dune sand accumulation (Fig. 4). The date of $10.60 \pm 0.13 \mathrm{ka}$ BP $(\mathrm{Ki}-8655)$ for the soil covering the second dune series points to its Alleröd age. It means that the second series was accumulated in the Older Dryas while the first in the Older and/or Oldest Dryas. The fact that the western part of the third series overlies the Alleröd soil and the existence of the soil dated at $5.45 \pm 0.10 \mathrm{ka} \mathrm{BP}(\mathrm{Ki}-8654)$ in the top part of the series indicate that this series was accumulated in the Younger Dryas. 


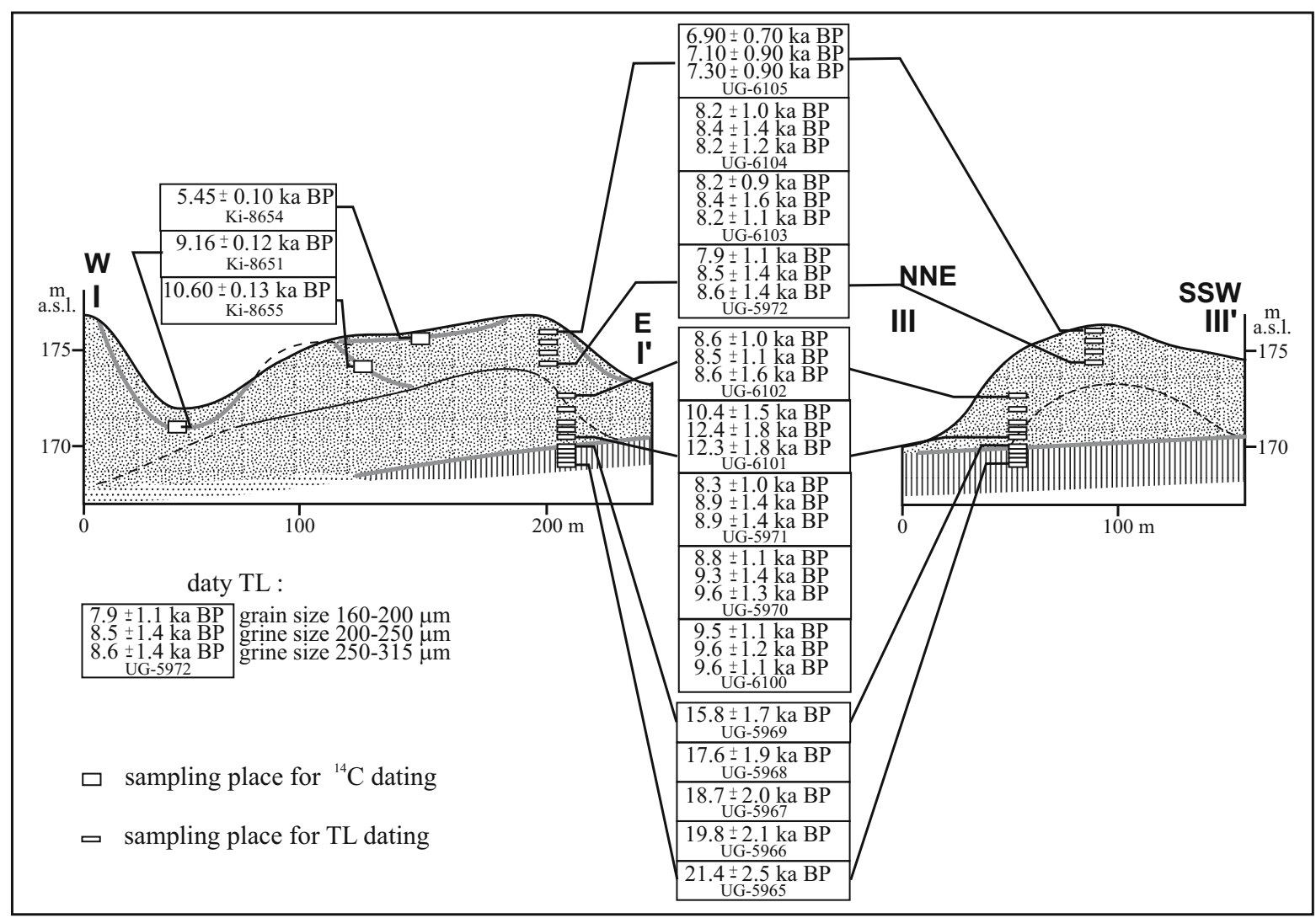

Fig. 4. Radiocarbon and TL dates against the transverse and longitudinal section of the form Localization of sections in Fig. 2B.

The time when the accumulation of this series was completed may be approximated by the date obtained from the interdune depression on the windward side of the analysed form $-9.16 \pm 0.12 \mathrm{ka} \mathrm{BP}$ (Ki-8651). The fourth series was accumulated in the Atlantic period, which is evidenced by the soil age $(5.45 \pm 0.10 \mathrm{ka} \mathrm{BP})$ in bottom part of the series (Rotnicki, 1970; Nowaczyk, 1976, 1986; Krajewski, 1977; Manikowska, 1985, 1991, 1995; Szczypek, 1986; Kozarski and Nowaczyk, 1991, 1992; Jaśkowski, 1996; Litt et al., 1998).

For the purposes of TL dating the profile in the ridge zone of the form (Fig. 4) was selected; it comprises both aeolian sand and loess. Dating of aeolian sand samples was treated methodologically (Table 2) and each of nine samples was dated in three or four fractions.

These were three fractions predominant in the samples, i.e. $0.16-0.20 \mathrm{~mm}, 0.20-0.25 \mathrm{~mm}, 0.25-0.315 \mathrm{~mm}$. The range of $0.08-0.10 \mathrm{~mm}$ was used only in 6 samples; this fraction is dated in the standard way in the TL laboratory in Gdańsk (Fedorowicz, 2006).

The TL results of loess dating, i.e. from $21.4 \pm 2.5$ to $15.8 \pm 1.7 \mathrm{ka} \mathrm{BP}$, point to its accumulation in the Plenivistulian. A large temporal span of dates in the 0.5 -meter segment suggests a small deposition rate, deposition intervals or periodical degradation (Maruszczak, 2001; Fedorowicz and Łanczont, 2007; Jary, 2007). Having regard to the profile localization in the higher loess terrace, it is degradation that seems to be the most probable cause (Fig. 1). At that time this area could have been frequently flooded during the Brodek Stream bank-full stages, which is additionally confirmed by loess gleying. Loess deposition most probably ended in the development of initial gley soil during a warmer climate oscillation, i.e. the epe interphase. It is implicated by the $15.8 \pm 1.7 \mathrm{ka}$ BP date obtained from the gley horizon in the top of loess. This horizon also indicates the lower temporal limit of aeolian sand accumulation.

The obtained TL dates of aeolian sand range from $6.6 \pm 0.7$ to $9.6 \pm 1.3 \mathrm{ka} \mathrm{BP}$ and are arranged chronologically; generally, within each sample, the finer the fraction the younger the date. The sample of Karczmiska III/9 is an exception: its dates are notably older, ranging from $10.2 \pm 1.5$ to $12.4 \pm 1.8 \mathrm{ka} \mathrm{BP}$ (Fig. 4, Table 2); however, the tendency concerning the fraction size is also observed. These results clearly indicate that in the dated profile sand deposition took place in the Younger Dryas. It shows conclusively that the first series has a limited extent which is much smaller than that determined by Zieliński (2006). Therefore, it may be supposed that aeolian sandy accumulation did not occur on the loess substratum of the dune in this place or previously deposited sediments were removed. The chronological order of dates in the profile points to the high applicability of the TL method to aeolian sand dating and confirms the high probability of correct luminescence dating (Bluszcz, 2000). 
Table 1. Results of loess TL dating.

\begin{tabular}{lccccc}
\hline Sample & Depth $(\mathbf{m})$ & Lab. No & Dr (Gy/ka) & ED (Gy) & TL age (ka BP) \\
\hline Karczmiska III/1 & 4.0 & UG-5965 & $2.65 \pm 0.10$ & $56.7 \pm 5.6$ & $21.4 \pm 2.5$ \\
Karczmiska III/2 & 3.9 & UG-5966 & $2.71 \pm 0.11$ & $53.6 \pm 5.3$ & $19.8 \pm 2.1$ \\
Karczmiska III/3 & 3.8 & UG-5967 & $2.83 \pm 0.12$ & $52.9 \pm 5.2$ & $18.7 \pm 2.0$ \\
Karczmiska III/4 & 3.7 & UG-5968 & $2.97 \pm 0.12$ & $52.3 \pm 5.2$ & $17.6 \pm 1.9$ \\
Karczmiska III/5 & 3.6 & UG-5969 & $2.84 \pm 0.11$ & $44.9 \pm 4.6$ & $15.8 \pm 1.7$ \\
\hline
\end{tabular}

The analysis of TL dates in subsequent fractions of the samples leads to interesting observations. The increase of age in proportion to the fraction size may implicate that increasingly coarser grains had worse conditions to get rid of their accumulated pregenetic energy. It could have been caused by shorter transport in comparison to finer grains and the resulting shorter exposure to solar energy. These facts may lead to the conclusion that the finest fraction is most suitable for luminescence dating. However, this conclusion may prove very fallacious because $0.08-0.10 \mathrm{~mm}$ fraction has a minor share in the sample, reaching even below $0.5 \%$.

The significantly different date in sample $\mathrm{K} \mathrm{III/9} \mathrm{is}$ worth considering. The date inversion may be caused by insufficient zeroing of pregenetic energy in the sample grains. It may be contributed to their brief contact with solar radiation which was most likely caused by very short transport from the source area to the deposition site. This thesis may be confirmed by the fact that all the four fractions of the sample have older dates than those identified in analogous neighbouring samples as well as dates older by ca. $20 \%$ from two coarser fractions compared to finer ones in this sample. Weak "zeroing" of the sample, which indicates short transport, suggests that sand from older dune series could have been deposited in this profile. The lithofacial analysis (Fig. 2D) shows that the bottom part of this profile was deposited on the slanting surface that was periodically exposed to wind. The most probable explanation seems to be profile localization in the leeward close area of the dune represented by the first series. The lack of fossil soils in this part of the dune may point to intensive deflation caused most probably by south-western and southern wind. In consequence these processes could have led to the undercutting of the

Table 2. Results of loess TL dating.

\begin{tabular}{|c|c|c|c|c|c|c|}
\hline Sample & Depth (m) & Lab. No & Dr (Gy/ka) & $\begin{array}{c}\text { Fraction } \\
(\mathrm{mm})\end{array}$ & $\begin{array}{c}\text { ED } \\
\text { (Gy) }\end{array}$ & $\begin{array}{c}\text { TL age } \\
\text { (ka BP) }\end{array}$ \\
\hline \multirow[t]{4}{*}{ Karczmiska III /14 } & 0.7 & UG-6105 & $2.74 \pm 0.14$ & $0.08-0.10$ & $18.10 \pm 0.18$ & $6.60 \pm 0.70$ \\
\hline & & & & $0.16-0.20$ & $18.90 \pm 0.20$ & $6.90 \pm 0.90$ \\
\hline & & & & $0.20-0.25$ & $19.50 \pm 0.19$ & $7.10 \pm 0.90$ \\
\hline & & & & $0.25-0.31$ & $20.00 \pm 0.19$ & $7.3 \pm 1.0$ \\
\hline \multirow[t]{4}{*}{ Karczmiska III /13 } & 1.0 & UG-6104 & $2.93 \pm 0.12$ & $0.08-0.10$ & $23.40 \pm 0.24$ & $8.0 \pm 1.0$ \\
\hline & & & & $0.16-0.20$ & $24.00 \pm 0.24$ & $8.2 \pm 1.0$ \\
\hline & & & & $0.20-0.25$ & $24.60 \pm 0.28$ & $8.4 \pm 1.4$ \\
\hline & & & & $0.25-0.31$ & $24.00 \pm 0.24$ & $8.2 \pm 1.2$ \\
\hline \multirow[t]{4}{*}{ Karczmiska III /12 } & 1.7 & UG-6103 & $2.91 \pm 0.11$ & $0.08-0.10$ & $23.30 \pm 0.22$ & $8.00 \pm 0.90$ \\
\hline & & & & $0.16-0.20$ & $23.90 \pm 0.23$ & $8.2 \pm 1.0$ \\
\hline & & & & $0.20-0.25$ & $24.40 \pm 0.25$ & $8.4 \pm 1.6$ \\
\hline & & & & $0.25-0.31$ & $23.90 \pm 0.23$ & $8.2 \pm 1.1$ \\
\hline \multirow[t]{3}{*}{ Karczmiska III /11 } & 2.0 & UG-5972 & $2.86 \pm 0.10$ & $0.16-0.20$ & $22.6 \pm 2.1$ & $7.9 \pm 1.1$ \\
\hline & & & & $0.20-0.25$ & $24.4 \pm 2.5$ & $8.5 \pm 1.4$ \\
\hline & & & & $0.25-0.31$ & $24.6 \pm 2.5$ & $8.6 \pm 1.4$ \\
\hline \multirow[t]{4}{*}{ Karczmiska III /10 } & 2.4 & UG-6102 & $2.89 \pm 0.12$ & $0.08-0.10$ & $24.00 \pm 0.24$ & $8.30 \pm 0.90$ \\
\hline & & & & $0.16-0.20$ & $24.80 \pm 0.25$ & $8.6 \pm 1.0$ \\
\hline & & & & $0.20-0.25$ & $24.60 \pm 0.25$ & $8.5 \pm 1.1$ \\
\hline & & & & $0.25-0.31$ & $24.90 \pm 0.25$ & $8.6 \pm 1.2$ \\
\hline \multirow[t]{4}{*}{ Karczmiska III /9 } & 2.7 & UG-6101 & $2.84 \pm 0.14$ & $0.08-0.10$ & $28.90 \pm 0.30$ & $10.2 \pm 1.5$ \\
\hline & & & & $0.16-0.20$ & $29.50 \pm 0.30$ & $10.4 \pm 1.5$ \\
\hline & & & & $0.20-0.25$ & $35.20 \pm 0.36$ & $12.4 \pm 1.8$ \\
\hline & & & & $0.25-0.31$ & $35.00 \pm 0.35$ & $12.3 \pm 1.6$ \\
\hline \multirow[t]{3}{*}{ Karczmiska III /8 } & 3.1 & UG-5971 & $2.94 \pm 0.12$ & $0.16-0.20$ & $24.4 \pm 2.5$ & $8.3 \pm 1.0$ \\
\hline & & & & $0.20-0.25$ & $26.3 \pm 2.8$ & $8.9 \pm 1.4$ \\
\hline & & & & $0.25-0.31$ & $26.2 \pm 3.0$ & $8.9 \pm 1.4$ \\
\hline \multirow[t]{3}{*}{ Karczmiska III /7 } & 3.3 & UG-5970 & $3.04 \pm 0.12$ & $0.16-0.20$ & $26.7 \pm 2.5$ & $8.8 \pm 1.1$ \\
\hline & & & & $0.20-0.25$ & $28.4 \pm 2.9$ & $9.3 \pm 1.4$ \\
\hline & & & & $0.25-0.31$ & $29.3 \pm 3.0$ & $9.6 \pm 1.3$ \\
\hline \multirow[t]{4}{*}{ Karczmiska III /6 } & 3.6 & UG-6100 & $2.88 \pm 0.13$ & $0.08-0.10$ & $26.20 \pm 0.27$ & $9.1 \pm 1.1$ \\
\hline & & & & $0.16-0.20$ & $27.30 \pm 0.28$ & $9.5 \pm 1.1$ \\
\hline & & & & $0.20-0.25$ & $27.70 \pm 0.28$ & $9.6 \pm 1.2$ \\
\hline & & & & $0.25-0.31$ & $27.70 \pm 0.28$ & $9.6 \pm 1.1$ \\
\hline
\end{tabular}


neighbouring dune slope and the slide of material which was subjected to transport in a very short time. In all likelihood the dates obtained in the study are the average value of source deposit and deposition age. Having regard to the fact that the neighbouring dates range from $8.3 \pm 0.6$ to $8.9 \pm 1.4 \mathrm{ka} \mathrm{BP}$, the source material could have been only slightly older than 12,000 years. In this context and considering the suggestion that coarser fractions are "bleached" to a smaller extent, it is significantly likely that the age of the first series is the Older Dryas. However, assuming that coarser fractions were zeroed to a larger extent, it may not be excluded that the deposition phase of the first series took place in the Oldest Dryas.

The problem of the first and the second series age determination will be solved more precisely after sampling and dating of profile in western part of dune which reference to ${ }^{14} \mathrm{C}$ dates. It will be possible, when exploitation of sand will restart in this part of exposure.

\section{FINAL REMARKS}

The following conclusions may be drawn from the presented material:

1) Loess, which constitutes the form substratum, was deposited in the Upper Plenivistulian. In the accumulation period there were intervals and/or degradation of deposited material, caused most likely by erosion during flooding stages of the Brodek Stream. Between dust and sand deposition there was a clear interval represented by the initial gley soil from the epe interphase.

2) Dune sand was accumulated in three stages/phases (Fig. 5):

a) in the first phase from the Oldest and/or Older Dryas, a stationary dune was formed by the wind from dominant northern-west direction (Fig. 5A), on the contact area of sandy and silty terrace; next the dune made a slight movement on the distance not smaller than the length of its base, in the ESE direction (Fig. 5B);

b) in the second phase from the Older Dryas, a migrating form entered from the west on the windward slope of the existing dune (Fig. 5C); in this phase the processes were slowed down by the development of vegetation during the Alleröd warming and by the formation of soil cover; it led to the development of a complex parabolic dune whose meridional extent was

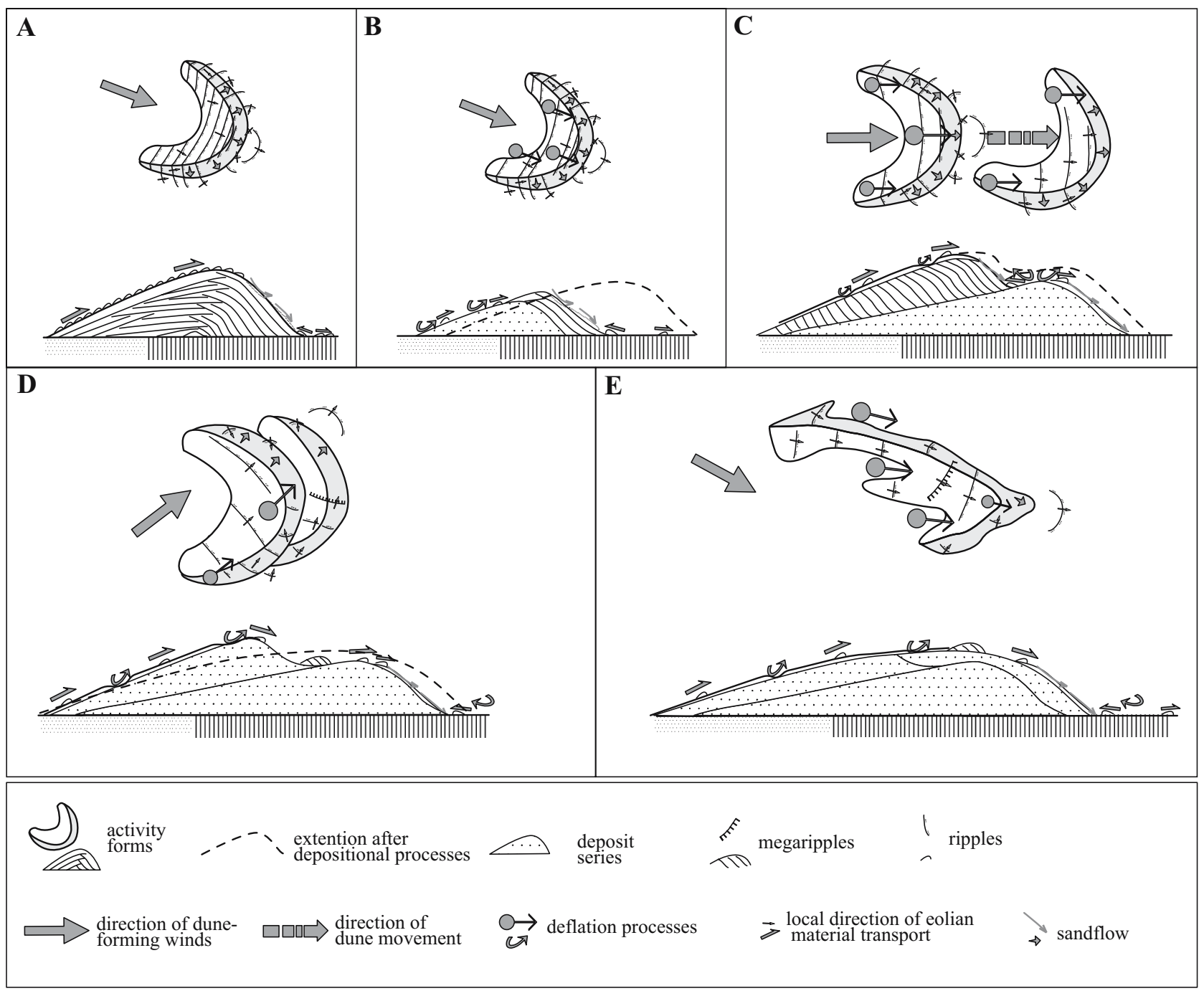

Fig. 5. Model of aeolian events. 
larger than the present form;

c) in the third phase from the Younger Dryas, the existing form was transformed by processes due to changeable wind, however mainly from the southern-western sector (Fig. 5D); the southern arm was shortened and material was deposited in the ridge and front area, creating the parallel elongated form; it is very likely that this phase ended in the Preboreal;

d) the last phase of aeolian processes from the Atlantic period was probably caused by the dune deforestation by human beings and comprised deflation and deposition processes in the form (Fig. 5E).

3) The luminescence dates obtained from the samples confirm that they are useful to reconstruct aeolian events and together with radiocarbon dates are an excellent tool to study dunes which offers additional interpretative possibilities. TL dates of various fractions have indicated that the youngest dates were obtained for the finest fractions; in the naturalist's opinion they are closest to age values expected by him.

4) Dating of various fractions in the sample shows insignificant age differences. In many cases the age of dated fraction is in direct proportion to its size. The aeolian sand dates presented in the paper (Table 2) may trigger similar research experiments on other similar profiles.

\section{REFERENCES}

Adamiec G and Aitken MJ, 1998. Dose-rate conversion factors: update. Ancient TL 16(2): 37-50.

Aitken MJ and Xie J 1985. Moisture correction for annual gamma dose. Ancient TL 8(2): 6-9.

Bagnold RA, 1954. The physics of blown sand and desert dunes. London, Methuen: 265pp.

Bluszcz A, 2000. Datowanie luminescencyjne osadów czwartorzędowych - teoria, ograniczenia, problemy interpretacyjne (Luminescence dating of Quaternary sediments- theory, limitations, interpretation problems). Geochronometria 17: 104 pp (in Polish).

Borówka KR, 1980. Współczesne procesy transportu i sedymentacji piasków eolicznych oraz ich uwarunkowania i skutki na obszarze wydm nadmorskich (Present-day transport and sedimentation processes of eolian sands - controling them factors and resulting phenomena on coastal dune area). Prace Komisji GeograficznoGeologicznej 20: 126pp (in Polish).

Borówka RK, 1990. The Holocene development and present morphology of Łeba Dunes, Baltic coast of Poland. In: Nordstrom KF, Psuty N and Carter B, eds., Coastal Dunes: form and proceses. J. Wiley \& Sons: 289-313.

Borówka RK, 2001. Struktura wewnętrzna wydm Łebskich jako efekt zmienności warunków meteorologicznych (Internal structure of dunes in Łeba as a result of changing meteorological conditions; lack of title and summary in English). In: Rotnicki K, ed., Przemiany środowiska geograficznegonizin nadmorskich poludniowego Bałtyku $w$ vistulianie i holocenie. Poznań, Bogucki Wyd. Nauk.: 89-93 (in Polish).

Brumby S, 1992. Regression analysis of ESR/TL dose-response data. Nuclear Trucks and Radiation Measurements 20: 595-599, DOI 10.1016/1359-0189(92)90010-S.

Buraczyński J, 1994. Rola procesów eolicznych w rozwoju pokryw piaszczystych na Roztoczu Tomaszowskim (Role of aeolian processes in the development of cover sands on Tomaszów Roztocze Upland). In: Vistuliańsko-holoceńskie zjawiska i formy eoliczne (wybrane zagadnienia). Poznań, SGP: 13-23 (in Polish).

Clemmensen LB and Abrahamsen K, 1983. Aeolian stratification and facies association in desert sediments, Arran basin (Permian), Scotland. Sedimentology 30(3): 311-339, DOI 10.1111/j.13653091.1983.tb00676.x.
Fedorowicz S, 2006. Metodyczne aspekty luminescencyjnego oznaczania wieku osadów neoplejstoceńskich Europy Środkowej (Methodological aspects of luminescence dating of Central Europe's Nopleistocene deposits. Gdańsk, Wydawnictwo Uniwersytetu Gdańskiego: 156 pp (in Polish).

Fedorowicz S and Lanczont M, 2007. Rate of Loess Accumulation in Europe in the Upper Weichselian (= Upper Vistulian). Geological Quaterly 5(2): 193-202.

Fryberger SG, Hesp P and Hatings K, 1992. Aeolian graule ripple deposits, Namibia. Sedimentology 39(2): 319-331, DOI 10.1111/j.1365-3091.1992.tb01041.x.

Goździk J, 1998. Struktury sedymentacyjne w eolicznych piaskach pokrywowych w Polsce (Sedimentary structures in aeolian cover sands in Poland). In: Mycielska-Dowgiałło E, ed., Struktury sedymentacyjne $i$ postsedymentacyjne $w$ osadach czwartorzędowych i ich wartość interpretacyjna (Sedimentological and postsedimentological structures in Quaternary sediments and their value for interpretation). Warszawa, UW: 167-191 (in Polish).

Grün R, 1994. Fit-Sim. Computer program, QDRC, Canbera.

Hunter RE, 1977. Basic types of stratification in small eolian dunes. Sedimentology 24(3): $361-387, \quad$ DOI $10.1111 / j .1365-$ 3091.1977.tb00128.x.

Jary Z, 2007. Zapis zmian klimatu w górnoplejstoceńskich sekwencjach lessowo-glebowych w Polsce i zachodniej części Ukrainy (Record of Climate Changes in Upper Pleistocene Loess-soil sequences in Poland and western part Ukraine). Rozprawy naukowe Instytutu Geografii i Rozwoju Regionalnego UWroc 1: 136pp (in Polish).

Jaśkowski B, 1996. Geneza i wiek wydm Gór Świętokrzyskich w świetle datowan ${ }^{14} \mathrm{C} \mathrm{i} \mathrm{Tl}$ (The genesis and age of the Holy Cross Mountains dunes in the light of ${ }^{14} \mathrm{C}$ and TL dating results). Zeszyty Naukowe Politechniki Ślaskiej 1331, Seria Mat-Fiz. 80. Geochronometria 14: 31-46 (in Polish).

Kozarski S, 1962. Wydmy w Pradolinie Noteci koło Czarnkowa (Dunes ih the Noteć Ice-Marginal Valley near Czarnków). Badania fizjograficzne nad Polska Zachodnia IX, Poznań: 37-60 (in Polish).

Kozarski S and Nowaczyk B, 1991. The Late Quaternary Climate and Human Impact on Aeolian Processes in Poland. Zeitschrift für Geomorphologie N.F., Supplmentband 93: 29-37.

Kozarski S and Nowaczyk B, 1992. Późnovistuliańskie i holoceńskie zjawiska eoliczne w regionie dolnej Odry i dolnej Warty (Litophacies variation and chronostratigraphy of Late Vistulian and Holocene aeolian phenomena in northwestern Poland). In: Szczypek T, ed., Wybrane zagadnienia geomorfologii eolicznej. UŚ, Sosnowiec: 37-105 (in Polish).

Krajewski K, 1977. Późnoplejstoceńskie i holoceńskie procesy wydmotwórcze w Pradolinie Warszawsko-Berlińskiej w widłach Warty i Neru (Late-Pleistocene and Holocene dune-forming processes in the Warshaw_Berlin Pradolina). Acta Geographica Lodziensia 39: $87 \mathrm{pp}$ (in Polish).

Krajewski K and Balwierz Z, 1985. Stanowisko Böllingu w osadach wydmowych schyłku Vistulianu w Roślu Nowym k/Dąbia (The site of Bölling in the dune sediments of the Vistulian decline at Rośle Nowe near Dąbie). Acta Geographica Lodziensia 50: 93-109 (in Polish).

Lea PD, 1990: Pleistocene periglacial aeolian deposits in southwestern Alaska: sedimentary facies and depositional processes. Journal of Sedimentary Petrology 60(4): 582-591.

Litt T, Stebich M and Brauer A, 1998. Bio- and chronostratigraphy of the Lateglacial in the Eifel region based on varved sediments. In: Mediterranean Lacustrine Records, $3^{\text {rd }}$ Workshop of the European Lake Drilling Programme. Terra Nostra 98(6): 82-88.

Manikowska B, 1970. Późnoplejstoceńskie gleby kopalne w wydmie koło Annopola nad Wisłą. (Les solis fossiles tradiglaciaires dans la dune prés d'Annopol sur la Vistule). Acta Geographica Lodziensia 24: 327-336 (in Polish).

Manikowska B, 1985. O glebach kopalnych, stratygrafii i litologii wydm Polski środkowej (On the fossil soils, stratigraphy and litology of the dunes in central Poland). Acta Geographica Lodziensia: 52pp (in Polish).

Manikowska B, 1991. Vistulian and Holocene aeolian activity, pedostratigraphy and relief evolution in Central Poland. Zeitschrift für Geomorphologie N.F., Supplmentband 90: 131-141.

Manikowska B, 1995. Aeolian activity differentation in the area of Poland during the Period 20-8 ka BP. Biuletyn Peryglacjalny 34: 125-166.

Maruszczak H, 2001. Schemat stratygrafii lessów i gleb śródlessowych 
w Polsce (Stratigraphic scheme of loesses and paleosols in Poland). In: Maruszczak H, ed., Podstawowe profile lessów w Polsce II (Main section of loesses in POland II) Wyd. UMCS, Lublin: 1729 (in Polish).

McKee ED, 1966. Structures of dunes at White Sands National Monument, New Mexico (and a comparison with structures of dunes from other selected areas). Sedimentology 7(1): 3-69, DOI 10.1111/j.1365-3091.1966.tb01579.x.

McKee ED, Douglass JR and Rittenhouse S, 1971. Deformation of leeside laminae in eolian dunes. Geological Society of America Bulletin 82: 359-378, DOI 10.1130/00167606(1971)82[359:DOLLIE]2.0.CO;2.

Murray AS and Clemmensen LB, 2001. Luminescence dating of Holocene aeolian sand movement, Thy, Denmark. Quaternary Science Reviews 20: 751-754, DOI 10.1016/S0277-3791(00)00061-5.

Mycielska-Dowgiałło E, 1982. Cechy teksturalne osadów eolicznych jako wskaźników faz wydmotwórczych (Tekstural features of aeolian sediments as indices of dune-forming stages). Roczniki gleboznawcze 33(3-4): 135-143 (in Polish).

Nowaczyk B, 1976. Geneza i rozwój wydm śródlądowych w zachodniej części pradoliny warszawsko-berlińskiej w świetle badań struktury, uziarnienia i stratygrafii budujacych je osadów (The genesis and development of inland dunes in the western part of the Warshaw-Berlin Pradolina in the light of examinations of the structure, granulation and stratigraphy of the deposits which built them). Prace Komisji Geograficzno-Geolgicznej, PTPN 16: 108pp (in Polish).

Nowaczyk B, 1986. Wiek wydm, ich cechy granulometryczne i strukturalne a schemat cyrkulacji atmosferycznej w Polsce w późnym vistulianie $\mathrm{i}$ holocenie (The age of dunes, their textural and structural properties against atmospheric circulation pattern of Poland during the Late Vistulian and Holocene). Seria Geografia 28. Poznań, Wyd. Naukowe UAM: 245pp (in Polish).

Poreba GJ and Fedorowicz S, 2005. Gamma spectrometry for OSL and TL dating of loess deposits at Dybawka and Tarnowce (SE Poland), Geochronometria 6: 27-32.

Pye K and Tsoar H, 1990. Aeolian sands and dunes. London, The Academic division of Unwin Hyman Ltd.: 400pp.

Rotnicki K, 1970. Główne problemy wydm śródladowych w Polsce w świetle badań wydmy w Węglewicach (Main problems of inland dunes in Poland based on investigations of the dune at Węglewice). Prace Komisji Geograficzno-Geologicznej, PTPN 11(2): 146pp (in Polish).

Sharp R.P, 1963. Wind ripples. Journal of Geology 71: 617-636.

Sharp R.P, 1966. Kelso Dunes, Mohave Desert, California. Geological Society of America Bulletin 77: 1045-1074, DOI 10.1130/00167606(1966)77[1045:KDMDC]2.0.CO;2.
Stankowski W, 1963. Rzeźba eoliczna Polski północno-zachodniej na podstawie wybranych obszarów (Eolian relief of north-west Poland on the ground of chosen regions). Prace Komisji Geograficzno-Geologicznej, PTPN 4(1): 146pp (in Polish).

Szczypek T, 1986. Procesy wydmotwórcze w środkowej części Wyżyny Krakowsko-Wieluńskiej na tle obszarów przyległych (Dune forming processes in the middle part of the Cracow-Wielun Upland against a background of the neighbouring area). Prace Naukowe UŚ 823: 193pp (in Polish).

Tobolski K, 1988. Paleobotanical study of Bölling at Żabinko in the vicinity of Poznań, Poland. Quaestiones Geographicae 10: 119 124.

Urbaniak U, 1969. Problematyka wydmowa w Polsce. In: Galon R, ed., Procesy i formy wydmowe w Polsce. Prace Geograficzne IG PAN 75: $355-368$.

Wojtanowicz J, 1969. Typy genetyczne wydm Niziny Sandomierskiej (Types génétiques de dunes dans le Bassin de Sandomierz). Annales UMCS B 24(1): 1-45 (in Polish).

Wojtanowicz J, 1970. Wydmy Niziny Sandomierskiej w świetle badan granulometrycznych (Les dunes du Bassin de Sandomierz á la lumiere de l'examen granulometrique). Annales UMCS B 25(1): 150 (in Polish).

Wojtanowicz J, 1999. Problem of occurrence and age (TL) of inland Plenivistulian dunes in Poland (on the example of Sandomierz Basin). In: Schirmer W, ed., Dunes and fossil soils. GeoArchaeoRhein 3: 43-53.

Zieliński P, 1999. Rola wiatrów północo-zachodnich w kształtowaniu wydm w późnym plejstocenie w okolicach Opola Lubelskiego (Wyżyna Lubelska) (The role of the north-western winds in duneforming process during the Late Pleistocene in Opole Lubelskie environs (the Lublin Upland). Annales UMCS B 54: 111-133 (in Polish).

Zieliński P, 2004. Modele rozwoju wydm w zachodniej części Wyżyny Lubelskiej (The models of dune development in the Western part of the Lublin Upland). In: Wojtanowicz J, ed., Formy $i$ osady eoliczne. SGP, Poznań: 77-84 (in Polish).

Zieliński P, 2006. Porównanie warunków depozycji późnovistuliańskich piasków eolicznych w Kotlinie Chodelskiej i na Wysoczyźnie Lubartowskiej (Comparasion of depositional conditions of the Late Vistulian aeolian snads in the Chodel Basin nad Lubartów Plain). In: Nowaczyk B, ed., Morfologiczne i sedymentologiczne skutki działalności wiatru. SGP, Poznań: 85-95 (in Polish).

Zieliński P, Fedorowicz S and Zaleski I, 2008. Conditions and age of aeolian sand deposition in the Volhynian Polesie (Ukraine). Geologija 50(3): 188-200.

Zieliński P and Issmer K, 2008. Propozycja kodu genetycznego osadów środowiska eolicznego (The proposal of genetic code of aeolian deposits). Przeglad Geologiczny 56(1): 67-72 (in Polish). 